\title{
Reprodution of the Cownose ray, Rhinoptera bonasus Mitchill, 1815 (Elasmobranchii, Rhinopteridae), in captivity and newborn care
}

\author{
Baldassin, P. $^{\text {a* }}$, Gallo, $H^{\text {a }}$ and Azevedo, $V G .^{\text {b }}$ \\ aAquário de Ubatuba, Rua Guarani, 859, Itaguá, CEP 11680-000, Ubatuba, SP, Brazil \\ 'Instituto de Pesca, Agência Paulista de Tecnologia dos Agronegócios - APTA, \\ Secretaria de Agricultura e Abastecimento - SAA/SP, \\ Estrada Prof. Joaquim Lauro Monte Claro, 2275, Ubatuba, SP, Brazil \\ *e-mail: veterinaria@aquariodeubatuba.com.br \\ Received April 10, 2008 - Accepted June 18, 2008 - Distributed November 30, 2008
}

The cownose ray, Rhinoptera bonasus Mitchill, 1815 belongs to the Rhinopteridae family. This semi-pelagic species is found in tropical and temperate seas and in estuaries, often forming large schools along the Eastern (Mauritania, Senegal and Guinea) and Western Atlantic Ocean (New England to Florida, Gulf of Mexico, Trinidad, Venezuela and Brazil) (Neer and Thompson, 2005). Its population index is not known, but groups of thousands of individuals may be seen during migration (Barker, 2006).

The Cownosed ray feed mainly on bivalve mollusks, crushing them with its powerful jaw musculature (Smith and Merriner, 1985). The R. Bonasus displays a non placental form of viviparity since direct maternal-embryonic connections are lacking (Hamlett et al., 1985). Females bear only one young, the fetus develops in the left uterus and the orientation of the embryo within the maternal uterus is the same as that of the mother with the wings rolled around the body dorsally (Hamlett et al., 1985). However, there are few cases of six pups reported (Smith and Merriner 1985; Neer and Thompson, 2005).

According to Barker, (2006), the species is nearly threatened to extinction. However, in Brazil this species is not on the national endangered list (MMA, 2003).

Most Elasmobranches are classified as K'strategists, due to their long life cycle, low fecundity and growth rate. Additionally, they can be caught virtually in any stage of their life cycle, by different methods of fishing, therefore being highly vulnerable (Cailliet and Bedford 1983, Kotas et al. 2005).

Since its opening in 1996, the Ubatuba Aquarium, located in Ubatuba, São Paulo State, Brazil, has three specimens of the cownose ray, one male and two females, held in an 850001 tank. It is a semi-open system with biological and mechanical filtration, skimmer, and UV and ozone water sterilization. The tank is illuminated by metal halide lamps and for half the day by direct sunlight.

In September 2003, courtship behavior was observed, and only one quick copulation during the afternoon, with one clasper insertion followed by white liquid spreading out from the female cloacae. During courtship, mating and gestation period, average physical and chemical parameters values monitored in the water tank were:
pH7.3, 0.25 ppm $\mathrm{NH}_{3}, 0.25$ ppm $\mathrm{NO}_{2}$, salinity 34 ppm and temperature $26{ }^{\circ} \mathrm{C}$. Finally, after 13 months gestation, in November $1^{\text {st }} 2004$, at dawn, the female gave birth to a male offspring.

The pup was born with $38 \mathrm{~cm}$ disc width and weighing $3.75 \mathrm{~kg}$. During the first two days, it swam irregularly near the surface, and was unable to reach the bottom of the tank to feed by itself. Therefore, during this short period, the animal was fed twice a day, using a feeding probe directly to the stomach, with a nutritive mixture of $5 \mathrm{~mL}(10 \mathrm{~mL}$ glucose $(50 \%), 10 \mathrm{~mL}$ of saline solution $(0.9 \%)$ and $5 \mathrm{~g}$ of live brine shrimp, Artemia salina). After that procedure, the pup began to swim to the bottom of the tank and moved progressively more regularly, trying to follow its parents. Two days after birth, the feeding mixture given by the probe was modified, becoming more similar to the characteristic food of rays. The mixture was composed of shrimp (50 g), grams of mollusks (100 g) and fish $(150 \mathrm{~g}), 10 \mathrm{~mL}$ of glucose $(50 \%), 10 \mathrm{~mL}$ of sodium chloride $(0.9 \%)$ and live brine shrimp $(5 \mathrm{~g}) .5 \mathrm{~mL}$ of the feeding mixture was given to the animal twice a day. Fish used in the mixture were the rake stardrum, Stellifer rastrifer, banded croaker Paralonchurus brasiliensis, whitemouth croaker, Micropogonias furnieri, king weakfish, Macrodon ancylodon, southern kingcroaker, Menticirrhus americanus, Brazilian sardinella, Sardinella brasiliensis and shorthead drum, Larimus breviceps. The pup started feeding by itself in the bottom 17 days after birth. On the $23^{\text {rd }}$ day after birth, it had grown to $46.5 \mathrm{~cm}$ disc width and $4.75 \mathrm{~kg}$, swimming in schools and following the behavior of adult animals.

According to Gonzalez (2004), 47 species of 13 families of sharks, and 31 species of nine families of rays, were born in captivity, with only three registers for the Rhinobatidae family: Rhinobatos lentiginosus. The specimens were born in aquariums, marine parks and other institutions where captive elasmobranches are studied.

Information about the reproduction of elasmobranches in captivity, particularly related to the survival and development of pups are scarce (Uchida et al., 1990). The first successful reports of ray reproduction [Uchida et al., 1990, with Aetobatus narinari (Euphrasen, 1790); Throson et al., 1983, with Potamotrygon motoro (Müller and Henle, 1841); and Luer and Gilbert, 1985, with Raja 
eglanteria (Bosch, 1800)] showed good prospects for the development of new techniques. In Brazil there are two cases of elasmobranches born in captivity, but the females were pregnant when captured in nature, which does not characterize ex situ reproduction (Gonzalez, 2004). This is the first ex situ reproduction case for Rhinoptera bonasus, according to the bibliography and there are no reports of elasmobranch reproduction in captivity in Brazil.

The study of elasmobranch reproduction in captivity should favor the observation of the different types of reproductive patterns of sharks and rays. Great differences may be observed, from oviparity to aplacental viviparity, so that it is difficult to use similar techniques for all of them (Demski, 1990). Standard procedures should thus be employed for each reproductive pattern. All the specimens born in captivity at the OEA (Okinawa Expo Aquarium) show a seasonal pattern. Births happen from April to November, when the water in the tank is between $22.8{ }^{\circ} \mathrm{C}$ to $24.9{ }^{\circ} \mathrm{C}$ (Uchida et al., 1990). The same author describes the reproductive behavior of a ray belonging to the species Rhinoptera javanica, in 14 June 1982, when the female mated with several males, two meters deep in the Okinawa Aquarium.

Pup survival still demands more special conditions. Newborns need special feeding and stability of the water parameters. It is impossible to completely eliminate stressful situations but all efforts should be made to keep the environment in adequate conditions, as similar as possible to the newborn's natural habitat and to provide for the well-being of the animal.

The reproduction of elasmobranches in captivity (ex situ) may become an important tool, helping to preserve the biodiversity of this important group, currently threatened by predatory fishing and environmental degradation (Demski, 1990). This opens up the possibility of maintaining self-sustainable stocks of captive animals for research, environmental education and repopulation, helping to prevent the extinction of many resident species.

Acknowledgements - The authors wish to express their thanks to Michael Walsh from Sea World of Florida, Max Rondon Werneck and Berenice Gomes Gallo from Projeto Tamar-ICMBio, Rogério Neves, Veronica Gama and Roberto
Seckendorff for critical reading and suggestions to improve the manuscript.

\section{References}

BARKER, AS., 2006. Rhinoptera bonasus IUCN 2007. 2007 IUCN Red List of Threatened Species: an on line reference. [March 27, 2008]. Available from: http://www.iucnredlist.org.

CAILLIET, GM. and BEDFORD, DW., 1983. The biology of three pelagic sharks from California waters, and their emerging fisheries: a review. Cal COFI Rep., vol. 24, p. 57-69.

DEMSKI, LS., 1990. Elasmobranch reproductive biology: implications for captive breeding. J. Aquaric. Aquat. Sci., vol. 5, no. 4, p. 84-95.

GONZALEZ, MMB., 2004. Nascimento da Raia-viola, Zapteryx brevirostris (Müller and Henle) (Chondrichthyes, Rhinobatidae), em cativeiro. Curitiba. Rev. Bras. Zool. vol. 21, no. 4, p. $785-788$

HAMLETT, WC., WOURMS, JP. and SMITH, JW. 1985. Stingray placental analogues: structure of trophonemata in Rhinoptera bonasus. J. Submicrosc. Cytol. vol. 17, no. 4, p. 541-550.

KOTAS, JK., PETRERE, MJR., AZEVEDO, VG. and SANTOS, SA., 2005. Pesca de emalhe e de espinhel-de-superfície na Região Sudeste-Sul do Brasil. REVIZEE - Score Sul. São Paulo: Instituto Oceanográfico - USP. p. 72. Série Documentos.

MMA, 2003. Lista Nacional das Espécies da Fauna Brasileira Ameaçadas de Extinção. [May 08, 2008]. Available from: http:// www.mma.gov.br/port/sbf/fauna/index.cfm.

NEER, JA. and THOMPSON, BA., 2005. Life history of the cownose ray, Rhinoptera bonasus, in the northern Gulf of Mexico, with comments on geographic variability in life history traits. Environ. Biol. Fisches., vol. 73, p. 321-331.

SMITH, JW. and MERRINER, JV., 1985. Food habits and feeding behavior of the cownose ray, Rhinoptera bonasus, in lower Chesapeake Bay. Estuaries, vol. 8, no. 3, p. 305-310.

UCHIDA, S., TODA, M. and KAMEI, Y., 1990. Reproduction of elasmobranches in captivity. In PRATT, HR., GRUBER, SH. and TANIUCHI, T. (Eds.). Elasmobranches as Living Resources: Advances in the Biology, Ecology, Systematics, and the Status of the Fisheries. US: Department of Commerce. NOAA Technical Report NMFS 90. p. 211-237. 